\title{
Profilaktyka kryzysu małżeństwa drogą do zdrowego społeczeństwa
}

Epoka działań post factum ujawnia swój destrukcyjny wymiar na gruncie małżeństwa, rodziny oraz szerszych społeczności, budowanych na społecznościach podstawowych, którymi są wyżej wymienione. Dzieje się tak dlatego, że istotnym elementem zarówno małżeństwa, jak i rodziny, są uczucia i emocje, które mają własną autonomię. Jak pokazuje wielowymiarowa praktyka życia (to, co faktycznie dzieje się z tymi społecznościami, jak i prowadzone $z$ nimi metodyczne zajęcia warsztatowe czy terapeutyczne), małżeństwa i rodziny słabo sobie radzą z uczuciami i emocjami, mimo że jest to wymiar życia małżeńskiego i rodzinnego wysoko ceniony przez ich członków. Ta nieporadność w sytuacji dużej aprecjacji uczuć i emocji okazuje się przyczyną rozluźnienia więzi i rozpadu małżeństwa, które stanowi fundament zdrowego funkcjonowania rodziny; szeregu patologii socjalizacyjnych i edukacyjnych dzieci, ale też pewnych deficytów w funkcjonowaniu osób dorosłych doświadczających wspomnianych trudności - dodajmy: deficytów znajdujących swoje odbicie w różnych wymiarach życia szerszych społeczności, w których osoby te przecież funkcjonują. Trudność sytuacji $\mathrm{w}$ analizowanej kwestii polega z jednej strony na kwestii autonomii uczuć, z drugiej natomiast na posługiwaniu się przez większość duszpasterzy Ko- 
ścioła katolickiego, który wnosi największy wkład pracy nad małżeństwem i rodziną, filozofią grecką. Eksponuje ona rozum i wolę, w tle pozostawiając kwestie uczuć i emocji. Skutkiem tego jest powstawanie w wielu małżeństwach zaszłości, z których trudno wyjść, finalizowanych rozpadem małżeństwa, a najczęściej rodziny, ponieważ poszczególne związki mają już najczęściej dzieci. Z powyższego krótkiego rysu problemu wynika, mimo że uwarunkowań o podobnej wymowie jest znacznie więcej, iż podstawowym oddziaływaniem przeciw rozpadowi małżeństwa, a w konsekwencji odzyskiwaniu zdrowia przez społeczności szersze może być profilaktyka kryzysu małżeństwa, a nie działanie post factum.

\section{Definicja profilaktyki kryzysu małżeństwa}

Próba ukazania, na czym polega profilaktyka kryzysu małżeństwa, wymaga zdefiniowania samego pojęcia „kryzys małżeństwa”. Jest to ważne tym bardziej, że w Polsce pojęcie to jest nadużywane, co wydaje się konsekwencją statycznego postrzegania samego małżeństwa jako stanu i bardzo rozpowszechnionego redukcjonizmu prawno-moralnego jego ujmowania. Pod pojęciem kryzysu małżeństwa rozumie się tu taką jego sytuację, w której współwystępują poważne czynniki destruujące dane małżeństwo, nagląca potrzeba zmiany aktualnej sytuacji i niepewne rokowania co do przyszłości związku' ${ }^{1}$. Tak zdefiniowane pojęcie kryzysu małżeństwa wysuwa na plan pierwszy czynnik lub czynniki destruujące dane małżeństwo, czyli zaburzające jego funkcjonowanie do tego stopnia, że jedno z małżonków bądź oboje odczuwają potrzebę zmiany istniejącej sytuacji natychmiast. Nie ulega wątpliwości, że potrzeba ta sytuuje się na poziomie emocjonalnym małżonka czy małżonków, jednak jej zaistnienie najczęściej jest generowane z dwu pozostałych poziomów relacji małżeńskiej, czyli poznawczej i behawioralnej. Bywa też, i to nierzadko, że pochodzi z poziomu emocjonalnego. Przykładowo - dzieje się tak wówczas, gdy jedno z małżonków jest niezdolne do nawiązania odpowiedniej relacji uczuciowej ze współmałżonkiem, choć $\mathrm{w}$ takich przypadkach deficytem są dotknięte również pozostałe wymiary relacji małżeńskiej. Pojawienie się naglącej potrzeby zmiany istniejącej sy2013, s. 11

K. Wojaczek, Profilaktyka kryzysu małżeństwa. Podstawy i praktyka, Lublin 
tuacji ujawnia najczęściej daleko posunięty proces destrukcji małżeństwa i jest sygnałem, że będące jej wyrazem, uczucia i emocje łączące małżonków zostały znacząco nadwyrężone. Biorąc pod uwagę autonomię uczuć, należy zadać pytanie o możliwość ich odbudowy. Oprócz tego zdolność uczenia się człowieka sprawia, że patologiczne zachowania zostały znacząco utrwalone. Oba te czynniki sprawiają, że powstaje realna obawa o rokowania związku trzeci czynnik definicji kryzysu małżeństwa ${ }^{2}$.

Powyższa definicja kryzysu małżeństwa, zakładająca dynamiczną koncepcję samego małżeństwa jako trwałego z założenia związku kobiety i mężczyzny, budowanego przez wzajemne obdarowywanie sobą małżonków na poziomie poznawczym, emocjonalnym i behawioralnym, otwiera drogę do zdefiniowania tendencji kryzysowej. Pod pojęciem tendencji kryzysowej małżeństwa rozumie się taką jego sytuację, w której występują nie wszystkie jednocześnie znamiona kryzysu, a tylko niektóre z nich. Najczęściej jest to układ istnienia czynnika bądź czynników zakłócających funkcjonowanie małżeństwa, które generują potrzebę usunięcia lub przynajmniej osłabienia oddziaływania tego czynnika lub czynników (nie całości związku). Trzeba zaznaczyć, że owa potrzeba zmiany niesie najczęściej pewną tolerancję czasową, która stopniowo ulega skróceniu, jeśli małżonkowie nie podejmą działań sanujących. Przyszłość związku na tym etapie nie jest zagrożona ${ }^{3}$. Wystąpienie tendencji kryzysowej w danym małżeństwie sygnalizuje konieczność niezwłocznego podjęcia działań profilaktycznych, bez których wejście małżeństwa w sytuację kryzysu, ze wszystkimi jego konsekwencjami, jest najczęściej jedynie kwestią czasu.

Sama idea profilaktyki kryzysu małżeństwa nie sprowadza się jednak do sytuacji pojawienia się tendencji kryzysowej w danym małżeństwie. Zdefiniowanie tendencji kryzysowej jest swego rodzaju dowodem na możliwość działań objętych pojęciem profilaktyki kryzysu małżeństwa. Pojawienie się tendencji kryzysowej $\mathrm{w}$ danym małżeństwie jest istotnym sygnałem konieczności jej wdrożenia. Sama idea profilaktyki małżeństwa, można rzec, jest pochodną pojawienia się w przestrzeni refleksji nad małżeństwem kilku czynników. Należą do nich: pojawienie się antropologii teologicznej, związanej z funkcjonalno-dynamiczną interpretacją pojęcia „obraz Boga w czło-

2 Fakty te powinni sobie uświadomić wszyscy amatorzy łatwego szermowania koncepcją umacniania małżeństwa poprzez kryzys.

$3 \quad$ K. Wojaczek, Profilaktyka..., dz. cyt., s. 22. 
wieku" ( $\mathrm{Rdz} 1,26-27)^{4}$ i wyprowadzaną z niego dynamiczną koncepcją relacji małżeńskiej; badania nauk szczegółowych, szczególnie psychologii, nad dynamicznym wymiarem małżeństwa ${ }^{5}$ oraz wypracowanie przez Sobór Watykański II doktrynalnych podstaw ${ }^{6}$ dla powstania metody synergii, rozwiniętych w encyklice Fides et ratio Jana Pawła II. Dodać należy, że ogromny wkład w rozwój antropologii teologicznej małżeństwa wniósł swoim nauczaniem papież Jan Paweł II, nie tylko w tzw. katechezach środowych, ale w wielu innych dokumentach swojego pontyfikatu. W tym miejscu koniecznie należy również zaznaczyć, że istotną rolę w przygotowaniu gruntu dla tzw. metody synergii miało nieprzyjęcie przez Sobór Watykański II socjologiczno-fenomenologicznej koncepcji relacji sacrum-profanum Durkheima i Eliadego, wykluczającej nie tylko powstanie metody synergii w spojrzeniu na małżeństwo i rodzinę, ale także naukę o inkarnacji. Niestety te kwestie nauczania soborowego do dnia dzisiejszego nie zyskały prawa obywatelstwa w polskim duszpasterstwie, a duszpasterstwie rodzin w szczególności ${ }^{7}$. Nie tylko w polskim duszpasterstwie, ale też na wydziałach teologii polskich uniwersytetów funkcjonuje koncepcja sacrum-profanum, co jest jednym z istotnych czynników utrudniających upowszechnianie profilaktyki kryzysu małżeństwa. Pojęcie profilaktyki kryzysu małżeństwa, w znaczeniu szerokim, znaczy podjęcie działań edukacyjnych i uświadamiających małżonków przede wszystkim w kwestiach modelu małżeństwa zgodnego z tym, co wynika z osobowego bycia tworzących go podmiotów: kobiety i mężczyzny, rozwiązań szczegółowych na poszczególnych poziomach jego funkcjonowania, czyli poznawczym, emocjonalnym i behawioralnym oraz podstawowych wymogów metodologicznych odnoszenia do siebie antropologii teologicznej i nauk szczegółowych, z których czerpią.

\footnotetext{
4 Por. M. Filipiak, Biblia o człowieku. Zarys antropologii biblijnej Starego Testamentu, Lublin 1979, s. 84.

5 Por. M. Braun-Gałkowska, Miłość aktywna. Psychiczne uwarunkowania powodzenia małżeństwa, Warszawa 1980, s. 116-122.

6 Szczególnie nauki o tzw. autonomii rzeczy ziemskich, Sobór Watykański II, konst. Gaudium et spes, 36.

7 Por. W. Świątkiewicz, Profanizacja Dies Domini. Między przyzwoleniem a zgorszeniem, w: Świętowanie dnia świętego w ekumenicznej refleksji Kościołów, red. A. Czaja, Z. Glaeser, Opole 2012, s. 43-62.
} 


\section{Metoda synergii: współpraca Kościoła i państwa}

Biorąc pod uwagę to, co powiedziano wyżej na temat wkładu Kościoła katolickiego w naukę o małżeństwie, wyraźnie wskazuje się na konieczność jego zaangażowania w dalszych działaniach, dotyczących tym razem profilaktyki kryzysu małżeństwa. Z drugiej strony nierzadkie rozbieżności konkretnego duszpasterstwa z oficjalną nauką Kościoła, przede wszystkim jednak konieczność odpowiedzi na pytania o to, jak tę czy ową kwestię rozwiązać w codzienności życia małżeńskiego, wymagają korzystania z nauk szczegółowych takich jak psychologia, socjologia, biologia, medycyna czy pedagogika. Już w tym momencie widać, że sprawa nie jest prosta, choćby ze względu na różnice metodologiczne uzyskiwania finalnych rezultatów odnoszenia do siebie z jednej strony badań teologicznych, a tych nauk szczegółowych z drugiej. Inny jest też status obowiązywania poszczególnych rozwiązań, choć kwestia ta nie jest tak trudna i nie do rozwiązania, jak się wydaje przedstawicielom redukcjonistycznego podejścia do małżeństwa, z jednej i drugiej strony.

Metoda synergii polega na równoległym opisie poszczególnych aspektów życia małżeńskiego dwoma torami: antropologii teologicznej bądź teologii oraz wybranych zagadnień z zakresu nauk szczegółowych. Zadaniem opisu z zakresu antropologii teologicznej (teologii) jest ukazanie modelu relacji małżeńskiej, wynikającego z faktu bycia podmiotów tworzących małżeństwo, mężczyzny i kobiety, osobami. Z zachowaniem pewnego poziomu uogólnienia można powiedzieć, że model ten zasadza się na wzajemnym byciu dla siebie wzajemnie, przez męża i żonę, darem. Chodzi przede wszystkim o bezinteresowność codziennego bycia dla siebie małżonków. Jan Paweł II wyprowadza ten model relacji małżeńskiej z „radykalnego obdarowania człowieka istnieniem przez Boga”, w sytuacji, w której człowiek w żaden sposób na to zaistnienie sobie nie zasłużył, bo go po prostu nie było ${ }^{8}$. Oprócz owego obdarowania w ramach wspomnianego modelu pojawiają się również inne jego elementy, które okazują się istotne z punktu widzenia profilaktyki kryzysu małżeństwa. Należy tu wspomnieć równość małżonków (każde z nich jest obrazem Boga), w konsekwencji poziomość relacji małżeńskiej czy też postrzeganie jej jako procesu. Wszystkie znacząco zmie-

8 Jan Paweł II, Mężczyzną i niewiastą stworzył ich. Chrystus odwołuje się do początku, Lublin 1981, s. 52. 
niają przeciętny na gruncie polskim sposób podejścia do małżeństwa, radykalnie ograniczając generowanie przez małżonków tendencji kryzysowych. Nierówne traktowanie małżonków (obojętnie, w którą stronę) i najczęściej z tym związane próby budowania pochyłej relacji między nimi zwykle eliminują model bycia wzajemnym darem i wprowadzają model rywalizacji i walki między nimi, dewastując ostatecznie więź emocjonalną, z którą małżonkowie, jak dowodzi praktyka, niezależnie od tego mają poważne trudności. Nieuwzględnianie w podejściu do małżeństwa faktu jego dynamiki i zmiany, czyli faktu, że jest ono procesem, współwystępuje najczęściej z pomijaniem konieczności uruchomienia aktywności własnej w jego codziennym budowaniu. Należy dodać, że ten aspekt funkcjonowania przedstawicieli naszego społeczeństwa jest słabo uświadamiany i rozwinięty, między innymi ze względu na uwarunkowania historyczno-społeczne, a jest on tym aspektem życia małżonków, który ostatecznie zdecyduje o udaniu bądź nie ich małżeństwa. Jak widać zarysowany model małżeństwa ma istotne znaczenie z punktu widzenia profilaktyki kryzysu. Jego głównym zadaniem, w odróżnieniu od wzoru, jest ukazanie małżonkom wyraźnego kierunku podążania w budowaniu ich małżeństwa.

Dla satysfakcjonującego budowania małżeństwa nie wystarczy mieć właściwy model, czyli wiedzieć, w którym kierunku należy iść. Każdy wybierający się w drogę wie, że istotną kwestią bezpiecznej podróży jest także wybór konkretnej trasy i środka bądź środków lokomocji w podróży dalekiej i złożonej. Podobnie jest z małżeństwem. Oprócz modelu małżonkowie potrzebują tzw. wiedzy know how, czyli rozwiązań szczegółowych poszczególnych kwestii czy problemów, które pojawią się na ścieżce ich małżeńskiej wędrówki. Chodzi tu przede wszystkim o wiedzę na temat mechanizmów funkcjonowania ich związku w konkretnych sytuacjach, np. porozumienia ze sobą, powstawania i rozwiązywania konfliktów, radzenia sobie z trudnymi emocjami i wiele, wiele innych. Wiedzy tej nie mogą zaczerpnąć z modelu, ponieważ on nie niesie tak szczegółowych danych i informacji na ich temat. Wiedzy tej dostarczają nauki szczegółowe, takie jak psychologia, socjologia, pedagogika, oraz przyrodniczo-medyczne: biologia i medycyna. Znajomość poszczególnych mechanizmów funkcjonowania związku małżeńskiego jest istotna w radzeniu sobie przez małżonków z problemami, które powstają w czasie jego trwania. Dzięki wiedzy np. na temat tego, jak funkcjonują uczucia, małżonkowie mogą się nauczyć radzenia sobie z nimi. Nie tylko tymi trudnymi, jak gniew, zawiść, nienawiść i inne, ale 
też w sytuacjach bycia obdarowanym przez małżonka uczuciami miłości, fascynacji swoją osobą i wieloma innymi. Niejednokrotnie to nieadekwatne reakcje małżonka na wyrazy uczuć i emocji współmałżonka są przyczyną nieporozumień i generują kolejne negatywne emocje. Dzięki wiedzy na temat mechanizmów porozumienia mogą uniknąć wielu konfliktów zainicjowanych nieporozumieniem, a te, które powstaną, łatwiej im będzie rozwiązać. Ponadto wiedza na temat mechanizmów funkcjonowania związku w poszczególnych sytuacjach, jakie mają miejsce na co dzień, daje im większe poczucie bezpieczeństwa, wówczas gdy coś układa się niezgodnie z ich oczekiwaniami. To z kolei umożliwia spokojniejsze podejście do trudnych sytuacji i ich łatwiejsze - najczęściej - rozwiązanie. W tym miejscu należy zaznaczyć, że w Polsce zarysowane wyżej podejście nie jest propagowane. Propagowane jest sięganie do doświadczenia innych małżeństw, np. w Ruchu Domowego Kościoła. Rozwiązanie takie niejednemu małżeństwu może rzeczywiście pomóc. Konieczne jest jednak wskazanie, że finalne rozwiązanie jakiegoś problemu, które sprawdza się w jednym małżeństwie, niekoniecznie sprawdzi się w innym. Jest wiele tego przykładów. Wystarczy porozmawiać z małżonkami. Dlatego należy położyć nacisk na poznanie przez małżonków mechanizmów funkcjonowania ich związku i wypracowywanie właściwych im rozwiązań. Każde małżeństwo jest inne, tak jak ludzie, którzy je tworzą. Dlatego tak ważna jest profilaktyka edukacyjna małżeństw.

W tym miejscu powstaje pytanie o to, po co w ogóle komplikować całe zadanie wprowadzaniem modelu? Czy nie wystarcza np. sama wiedza psychologiczna? Wielu małżonków rzeczywiście postępuje w ten sposób, kierując się w postępowaniu wobec współmałżonka wyłącznie wiedzą z zakresu psychologii czy innych nauk szczegółowych. Analiza rezultatów uzyskiwanych często przez wybierających taką opcję postępowania małżonków dowodzi, że nie jest to do końca rozwiązanie bezpieczne - z wielu powodów. Wśród nich należy wskazać choćby takie jak aspektowość ujmowania człowieka przez daną naukę szczegółową, dochodzenie niejednokrotnie do rozbieżnych wniosków, dzisiaj zależność od źródeł finansowania badań, niejednokrotnie nierespektowanie zasad etycznych małżeństwa i wiele innych. Z powyższych racji w metodzie synergii konieczne jest pokazanie zarówno modelu (antropologia teologiczna, teologia), jak i rozwiązań know how, czerpanych właśnie z nauk szczegółowych. Przyjmuje się, że w pracy warsztatowej z małżeństwami dopuszcza się takie rozwiązania z nauk szczegółowych w danej kwestii, które są zgodne z modelem. W takiej sytuacji ryzyko przekazu roz- 
wiązań błędnych praktycznie nie istnieje, ponieważ wskazania uzyskiwane przez małżonków z dwóch różnych źródeł wzajemnie się wzmacniają. Jest to bardzo ważne, również z punktu widzenia uruchomienia u małżonków aktywności własnej na rzecz udania się ich związku. Niezastosowanie tej zasady znacząco osłabia ich poczucie bezpieczeństwa oraz zdecydowanie osłabia motywację podjęcia znacznego wysiłku pracy na rzecz rozwoju swojego małżeństwa. Wzrastająca liczba rozwodów ma tu jedno ze swoich istotnych źródeł. Polem analizy rozwiązań rozbieżnych czy wręcz sprzecznych z modelem są katedry uniwersytetów, a nie dydaktyka i warsztaty z małżeństwami. Przyjęcie zatem modelu jako swego rodzaju kryterium doboru rozwiązań szczegółowych (know how) w dydaktyce pracy z małżeństwami nie gwałci w żaden sposób autonomii nauk szczegółowych, z których korzysta. Jest natomiast zgodne z wymaganiami skutecznej dydaktyki.

Praca z małżeństwami metodą synergii wymaga poinformowania ich o różnym statusie pewności ukazywanych im rozwiązań, w zależności od metod, jakimi zostały uzyskane. Wymaga też poinformowania ich o charakterze obowiązywalności. Przykładowo uzyskanych z nauk szczegółowych sposobów rozwiązywania konfliktów jest wiele i małżonkowie mogą sobie wybrać ten, który im najbardziej odpowiada i pomaga rozwiązywać ich konflikty. Nie mogą natomiast traktować w sposób dowolny takich kwestii jak nierozerwalność ich związku, wierność współmałżonkowi i wiele innych, których podważanie kwestionuje sam model przyjętego związku. Dla osób wierzących byłoby to odrzuceniem nauki Chrystusa o małżeństwie, kontynuowanej przez Kościół, którego są członkami.

Trudno przecenić wartość metody synergii w pracy z małżeństwami. Jej struktura jednoznacznie ukazuje przestrzenie współpracy Kościoła i państwa. Spotykanie się modelu z rozwiązaniami know how jest swego rodzaju paradygmatem tej współpracy. Chodzi nie tylko o samą merytoryczną treść modelu, ale także jego kontekst, czyli odniesienie do wiary małżonków i ich życia sakramentalnego, czyli samego faktu bycia ich małżeństwa widzialnym uobecnieniem relacji miłości Chrystusa z Kościołem oraz jego związku z pozostałymi sakramentami, przede wszystkim chrztem świętym, Eucharystią i sakramentem pojednania. Stopień trudności, jaki rysuje się dzisiaj przed małżonkami w budowaniu trwałego i wiernego małżeństwa i świadczenia tą drogą o Chrystusie, do którego należą, staje się znakiem czasu odkrycia na nowo sakramentu bierzmowania. Sprawa ta wydaje się 
słabo obecna w polskim duszpasterstwie. Ponadto po stronie Kościoła $\mathrm{w}$ analizie poruszanej kwestii należy wskazać zagadnienie budowania środowiska wsparcia dla małżeństw ${ }^{9}$. Ponownie swego rodzaju znakiem czasu należy określić zbieżność warunków, jakimi dysponuje Kościół katolicki w Polsce z rozwijającą się świadomością konieczności budowania środowiska wsparcia małżeństw, w procesie wzmacniania ich trwałości wobec narastających zagrożeń.

Terenem wkładu państwa w tej materii są najpierw uczciwe i rzetelne badania problematyki małżeństwa i rodziny w ramach uniwersytetów. Nie jest to sprawa łatwa, zważywszy współczesne sposoby finansowania takich badań i częste premiowanie badań sprofilowanych ideologicznie w taki sposób, że wspierają obowiązującą poprawność, a niekoniecznie rozwój małżeństwa i rodziny, np. ideologii gender. Ważnym sektorem współpracy państwa, ciągle w ramach funkcjonowania szkolnictwa wyższego, jest stworzenie warunków awansu naukowego dla naukowców niepoddających się naciskom ideologicznym w kwestiach dotyczących małżeństwa i rodziny. Kolejnym obszarem jest prowadzenie badań nad kwestiami rozbieżnych rezultatów między pochodnymi antropologii teologicznej a nauk szczegółowych. Kolejnym ważnym obszarem wkładu państwa w omawianą współpracę jest rzetelne kształcenie nauczycieli w zakresie wiedzy na temat małżeństwa i rodziny do pracy dydaktycznej na wszystkich poziomach szkolnictwa. Przygotowanie to powinno obejmować również znajomość metody synergii, przede wszystkim jej założeń i wymogów metodologicznych. W tej materii jest wiele do zrobienia, ponieważ w obecnej sytuacji wydaje się dominować podejście ideologiczne do małżeństwa i rodziny, sprzeczne z zapatrywaniami większości rodziców uczęszczających do szkół dzieci.

\section{Społeczne korzyści z profilaktyki kryzysu małżeństwa}

Korzyści, jakie społeczeństwo może wynieść z upowszechnienia profilaktyki kryzysu małżeństwa, wydają się już wymierne. Nie ulega wątpliwości, że pierwszą z nich będzie wzrost trwałości rodziny i podniesienie sprawności pełnionych przez nią funkcji. Trwałość rodziny bazuje na

9 Por. K. Wojaczek, Małżeństwo doświadczenie obdarowania, Opole-Lublin 2001, s. $65-76$. 
trwałości małżeństwa. Spadek trwałości małżeństwa i jego rozpad skutkują najczęściej, w dzisiejszych uwarunkowaniach społecznych jego funkcjonowania, rozwodem, ze wszystkimi negatywnymi konsekwencjami dla zbudowanej na nim rodziny. Zaburzeniu w tym wypadku ulegają niemal wszystkie funkcje rodziny - że wspomniane tu zostaną jedynie niektóre z nich, takie jak socjalizacyjna, wychowawcza, integracyjna, prokreacyjna i inne. Należy zdać sobie sprawę z tego, że rodzina jest jedyną komórką życia społecznego dysponującą niepowtarzalnymi w innych mechanizmami identyfikacji i naśladownictwa oraz modelowania, które w wypadku jej dezintegracji ulegają daleko idącym zaburzeniom, narażając dzieci na trudności rozwojowe i częstsze uczestnictwo w patologicznych przejawach życia społecznego. Konsekwencją tego są koszty ponoszone przez społeczeństwo i państwo na różnorakie formy terapii ich uczestników. Wspomnieć tu trzeba również o pewnym łańcuchu negatywnych konsekwencji rozbitej rodziny, czyli powstaniu pewnych skłonności do powielania niewłaściwych zachowań u dorosłych, którzy doświadczyli rozpadu własnej rodziny. Prześledzenie historii życia osób doświadczających kryzysu swojego małżeństwa i jego rozpadu pozwala niejednokrotnie znaleźć podobne doświadczenia ich rodziców.

Korzyści, jakie może wynieść społeczeństwo z profilaktyki kryzysu małżeństwa, nie ograniczają się do zbudowanej na nim rodziny, szczególnie dzieci, ale pochodzą z poprawnego funkcjonowania w życiu społecznym samych małżonków. Każdy, kto zetknął się z małżonkami pozostającymi w sytuacji kryzysu swojego małżeństwa, wie, że nie jest to sytuacja, która sprzyja ich społecznej integracji, zaangażowaniu nie tylko w życie społeczne, ale również w życie zawodowe. Doświadczanie kryzysu w relacji z człowiekiem najbliższym, jakim jest współmałżonek, tak głęboko angażuje najczęściej każdego z nich, że odbija się to, i to w sposób znaczący, na ich pracy zawodowej. Oczywiście można tłumaczyć, że praca zawodowa może być ucieczką od trudnej sytuacji w małżeństwie. Twierdzenie takie jest jednak iluzoryczne, ponieważ nie można wyizolować negatywnych przeżyć i doświadczeń człowieka od całości jego aktywności, w tym aktywności zawodowej. Analogicznie do ograniczających aktywność zawodową dolegliwości człowieka spowodowanych chorobą, nie mniejsze ograniczenia mogą nieść dolegliwości wynikające $\mathrm{z}$ dezorganizacji życia prywatnego pracownika. Uniknięcie kryzysu małżeństwa i ewentualnych dalszych perturbacji spowodowanych jego rozpadem jawi się wyraźnie korzystnie z punktu widze- 
nia jego pracy zawodowej i funkcjonowania firmy, dla której pracuje. Będą to korzyści nie tylko w zakresie jego wydajności jako pracownika, ale być może przede wszystkim jakości wykonywanej pracy, wymagającej np. dobrej koncentracji.

Kwestia społecznych korzyści z profilaktyki kryzysu małżeństwa wydaje się jednak sytuować przede wszystkim w kultywowaniu fundamentalnych dla człowieka wartości w małżeństwie i rodzinie. Godność człowieka, wartość małżeństwa i rodziny, przekazywanie i ochrona życia ludzkiego i wiele innych to wartości, które są eksponowane w działaniach profilaktycznych. Profilaktyka, o której mowa wyżej, obejmuje pogłębioną refleksję małżonków nad tym, czym jest małżeństwo, zarówno nad jego modelem, jak i mechanizmami (know how) jego funkcjonowania, nad koniecznością uruchomienia aktywności własnej obojga małżonków, po to by te wartości obronić przed anihilacją z powodu popełnianych błędów, bezczynności czy egoizmu. Nie ulega wątpliwości, że trud i wysiłek małżonków podejmujących działania osłonowe dla własnego małżeństwa i rodziny skutkuje pogłębieniem świadomości istnienia wspomnianych wyżej wartości, dla których jest on podejmowany. Wartości te stanowią fundament życia i ładu społecznego. Ich świadomość $\mathrm{i}$ kultywowanie w rodzinie stanowi środowisko wzrastania nowych obywateli, z których zdecydowana większość przyjmie je za swoje. $\mathrm{W}$ ten sposób odporne na kryzysy rodziny kładą mocne fundamenty pod zdrowe, silne, świadome swojej tożsamości społeczeństwa.

\section{Rezerwy polskiego duszpasterstwa rodzin w angażowaniu się w profilaktykę kryzysu małżeństwa}

Powyższe sformułowanie zagadnienia nie oznacza, że polskie duszpasterstwo rodzin nie angażuje się w przeciwdziałanie kryzysowi małżeństwa. Każde działanie zmierzające do poprawienia np. kondycji moralnej życia małżeńskiego ma również wymiar profilaktyki kryzysu. To nie ulega wątpliwości. Jeśli chodzi jednak o zaangażowanie pełne, o którym mowa wyżej, zaangażowanie wykorzystujące w pełnej skali naukę Kościoła w tej materii, to polskie duszpasterstwo rodzin pozostawia wiele do życzenia. Jest przynajmniej kilka kwestii, o których w tym kontekście należy wspomnieć. Najpierw jest to kwestia samego spojrzenia na małżeństwo. Jeśli prześledzić 
stronę merytoryczną poruszanych zagadnień z jednej strony i obsadę personalną duszpasterskich stanowisk z drugiej, to nie ulega żadnej wątpliwości, że mamy do czynienia $\mathrm{z}$ redukcjonizmem prawno-moralnym ujmowania małżeństwa i rodziny. Regularne powierzanie tych stanowisk specjalistom z zakresu teologii moralnej czy prawa kanonicznego jest wymowne. Nikt nie kwestionuje wagi zagadnień prawnych i moralnych życia małżeńskiego. Jednak nie ulega również wątpliwości, że pominięcie reszty jest poważnym błędem pozostawienia przestrzeni dla rozwoju poważnych kryzysów i degradacji małżeństwa.

Poważnym błędem jest niepodjęcie przez Kościół katolicki w Polsce dynamicznego ujęcia sakramentalności małżeństwa, wyraźnie wyłożonej przez Jana Pawła II w adhortacji Familiaris consortio (13 i 19), podjętej przez papieża Franciszka. Uporczywe trzymanie się podejścia historycznego do tego sakramentu pozbawia małżonków istotnego, z punktu widzenia ich świadomości eklezjalnej, wkładu w budowanie Kościoła codziennym życiem małżeńskim. Oprócz tego niesie ono silną motywację psychologiczną dbania o ich relację miłości, której małżonkowie w Polsce są pozbawieni. Ponadto dynamiczne ujęcie sakramentalności małżeństwa stanowi doskonałą bazę programową do prowadzenia różnorakich zajęć z małżeństwami w ramach podejścia synergicznego. Dodać należy bazę programową, wykluczającą szereg błędów, z którymi de facto mamy do czynienia obecnie $\mathrm{w}$ duszpasterstwie rodzin. Błędy te pochodzą chociażby z nieograniczonego kryterium modelowego wprowadzania różnych rozwiązań z zakresu nauk szczegółowych. Cała gwarancja zgodności przekazu z nauką Kościoła sprowadza się najczęściej do uznania danego duszpasterza dopuszczającego do zajęć takiego czy innego lekarza, psychologa czy innego przedstawiciela nauk szczegółowych.

W wyniku utrwalenia się pewnej praktyki w Polsce pracownicy duszpasterstwa rodzin mają częsty kontakt z ludźmi zawierającymi małżeństwo, których wiara, nie wspominając o wiedzy, jest dość odległa od oczekiwań. Przyjęło się minimalne ich traktowanie, to znaczy kilka spotkań ogólnych, najczęściej w formie podawczej, i kilka spotkań w tzw. poradni, dotyczących problematyki regulacji poczęć. Tymczasem chodzi przecież o duszpasterstwo, czyli doprowadzenie konkretnego człowieka, w jego aktualnych uwarunkowaniach życiowych do spotkania z Bogiem. Wydaje się, że dla być może nawet większości tych, o których tu mowa, znacznie korzystniejsza 
byłaby metoda synergii. Jej bardzo silną stroną jest aspekt przygotowania do wiary (preewangelizacji), nie wykluczając jej pogłębienia. Wynika on z ukazania zbieżności rozwiązań teologicznych kwestii małżeńskich i rozwiązań czerpanych z nauk szczegółowych, które w przekazie popularnym bardzo często są przeciwstawiane wierze i ujęciom teologicznym i równocześnie wynoszone na piedestał jako jedyne godne współczesnego człowieka. Wykorzystanie metody synergii jest równoznaczne z wprowadzeniem istotnych elementów profilaktyki kryzysu. Jednak wykorzystanie metody synergii w procesie przygotowania do małżeństwa wymagałoby nieco innego przygotowania pracowników duszpasterstwa rodzin, zarówno świeckich, jak i duchownych.

Ważną rezerwą polskiego duszpasterstwa rodzin są spore możliwości tworzenia środowisk wsparcia dla małżeństw i rodzin. Konieczność wsparcia małżeństwa i rodziny przez środowisko w sytuacji dokonanych i dokonujących się przemian społecznych, ekonomicznych i kulturowych od dawna nie ulega wątpliwości. Jest ona przede wszystkim konsekwencją utraty przez małżeństwo oparcia w środowisku szerokiej, wielogeneracyjnej rodziny. Kościół katolicki w Polsce, jako instytucja, która zajmowała się i zajmuje małżeństwem $\mathrm{z}$ racji jego sakramentalności, a rodziną z racji jej eklezjalności, niestety nie podjął systematycznych działań w tym kierunku. Nie oznacza to, że tych działań nie ma w ogóle. Przykładowo można wskazać istnienie znaczących elementów środowiska wsparcia w niektórych ruchach religijnych, np. Ruchu Domowego Kościoła. Dzięki jego doświadczeniom wiemy praktycznie, jak pozytywne skutki dla funkcjonowania małżeństwa niesie środowisko wsparcia. Kościół katolicki w Polsce ma dobrze rozwinięte zaplecze lokalowe i sieć poradni życia rodzinnego, które stanowią okoliczności sprzyjające powstawaniu środowiska wsparcia (konieczność spotykania się poszczególnych grup małżeństw). Istotnym czynnikiem sprzyjającym budowaniu środowiska wsparcia małżeństw i rodzin w parafiach jest zbieżność tego typu działania z ewentualnymi dążeniami do przebudowy struktur parafii w tzw. wspólnotę wspólnot, co od dawna sugeruje socjologia parafii. Niestety istnieją też czynniki utrudniające takie działania, i to zarówno po stronie duszpasterstwa, jak po stronie samych małżonków. Po stronie małżonków trudność jest ta sama co w przypadku rozwijania profilaktyki kryzysu małżeństwa, czyli brak świadomości istotnej roli aktywności własnej małżonków. Środowisko wsparcia małżeństw i rodzin wy- 
maga zaangażowania się małżonków w jego powstanie i utrzymywanie, po to by można z niego korzystać. Po stronie duszpasterstwa podstawowym mankamentem nie jest, jak się wydaje, kwestia świadomości jego potrzeby, ale sama wizja duszpasterstwa i jego priorytety. Samo duszpasterstwo w Polsce jest ewidentnie zorientowane na praktyki religijne i niedowartościowanie, a czasem wręcz pomijanie pozostałych parametrów religijności, w tym parametru wiedzy i konsekwencyjnego. Dotyczy to również duszpasterstwa małżeństw i rodzin. Jeśli już są podejmowane działania niosące elementy wiedzy, to najczęściej w masowych zgromadzeniach, a nie małych grupach ułatwiających internalizację poznanych treści i, co ważne z punktu widzenia budowania środowiska wsparcia, możliwości nawiązywania relacji face to face i ich rozwijania. Takie priorytety pochodzą, jak się wydaje, z głęboko zakorzenionego u wielu duszpasterzy dualizmu sacrum-profanum, opartego o radykalną antyinkarnacyjną koncepcję Durkheima i Eliadego ${ }^{10}$, zamiast soborowej nauki o słusznej autonomii spraw doczesnych i podmiotowości ludzi świeckich, w tym małżonków, w Kościele. Środowisko wsparcia obejmuje jego funkcję psychologiczną, socjalno-ekonomiczną i ludyczną. Ukazanie znaczenia teologicznego zaangażowania małżonków w każdą z nich wymaga odwołania się do teologii wcielenia, a dalej uszczegółowienia w ramach dynamicznie ujętej sakramentalności małżeństwa i eklezjalnego wymiaru rodziny. Koncepcja Durkheima i Eliadego praktycznie wyklucza taką możliwość, dlatego ta trudność duszpasterstwa rodzin wydaje się najpoważniejsza w uruchomieniu jego rezerw, w tym również tworzenia środowiska wsparcia małżeństwa i rodziny.

Podsumowując, należy stwierdzić, że społeczeństwo może wynieść wiele korzyści z profilaktyki kryzysu małżeństwa. Jej atutem jest niedopuszczenie do poważnej destrukcji małżeństwa, z którą często mamy do czynienia w sytuacji kryzysu, szczególnie przeciągającego się. Dzięki profilaktyce można uniknąć sporych kosztów ekonomicznych będących konsekwencją kryzysu, szczególnie gdy ten doprowadza małżonków do rozwodu. Jeszcze większe korzyści społeczeństwo wynosi z zachowania dobrej kondycji rodzin na małżeństwach budowanych.

10 Por. W. Świątkiewicz, Profanizacja..., dz. cyt., s. 47-50. 


\section{Bibliografia}

Braun-Gałkowska M., Miłość aktywna. Psychiczne uwarunkowania powodzenia mał̇eństwa, Warszawa 1980.

Filipiak M., Biblia o człowieku. Zarys antropologii biblijnej Starego Testamentu, Lublin 1979.

Jan Paweł II, Mężczyzna i niewiasta stworzył ich. Chrystus odwołuje się do początku. O Jana Pawła II teologii ciała, red. T. Styczeń, Lublin 1981.

Świątkiewicz W., Profanizacja Dies Domini. Między przyzwoleniem a zgorszeniem, w: Świętowanie dnia pańskiego w ekumenicznej refleksji Kościołów, red. A. Czaja, Z. Glaeser, Opole 2012, s. 43-62.

Wojaczek K., Mał̇̇eństwo, doświadczenie obdarowania, Opole-Lublin 2001.

Wojaczek K., Profilaktyka kryzysu małżeństwa. Podstawy i praktyka, Lublin 2013. 
